\title{
Against Alienation: The Emancipative Potential of Critical Pedagogy in Fromm
}

\section{Rafael D. Pangilinan}

C ritical theory generally refers to a series of pathways for Marxistinspired intellectual inquiry that first emerged with the end of the $18^{\text {th }}$

century European Enlightenment and in particular with the initial widespread waning of intellectual confidence that the newly hegemonic bourgeois society would succeed in realizing Enlightenment ideals. In short, it represents the intellectual articulation of the conviction that modern capitalist society cannot - at least not without significant reformation or substantial transformation-realize the Enlightenment ideal of an enlightened society. According to Enlightenment consensus, this (ideal) society is to be one which will genuinely embody the highest values of human civilization, and which will thereby insure steady progress in the attainment of liberty, justice, prosperity, and contentment for all of its citizens.

In a more focused sense, critical theory designates several generations of German philosophers and social theorists in the Western European Marxist tradition known as the Frankfurt School, which is particularly associated with the Institute for Social Research at the University of Frankfurt am Main. In order to fill in the perceived omissions of traditional Marxist thought, the Frankfurt School theorists sought to draw answers from other schools of thought, hence using the insights of psychoanalysis, Weberian theory, aesthetic modernism and other disciplines. The school's main figures attempted to overcome the limits of positivism, materialism and determinism by returning to Immanuel Kant's critical philosophy and its successors in German idealism, principally G.W.F. Hegel's philosophy, with its emphasis on dialectic and contradiction as inherent properties of reality. ${ }^{1}$ In a nutshell, the theorists of the Frankfurt School aimed not at a cool description but a radical transformation of the social world of advanced capitalism that will bring freedom for all from features of modern society that restrict or constrain individuals from living in freedom. It does not aim to bring about social change through revolutionary means, through confronting the practical and economic arrangements with political opposition. In a major development from Karl Marx's analysis of capitalism, it recognizes that culture is as much a

1 Tim Dant, Critical Social Theory: Culture, Society, and Critique (London: Sage, 2003), 156165. 


\section{AGAINST ALIENATION}

determinant of the form of society as political economy. Any change in the form of society will ultimately have economic and political effect but it cannot be achieved without transformation of the culture of modernity. The form of society has a material dimension: the economic and practical arrangements for meeting needs, the laws governing social actions and the specific institutions that make practical arrangements. But the material form of society is given meaning, communicated and understood through the society's culture: the ideas, understanding, reasons, images, writing and other modes of expression that accompany the material dimension. Frankfurt School critical theory mounts its critique of society as culture, rather than as political system or economy. Culture is treated not simply as the artistic and communicative stuff of society but as the way that ordinary lives are lived: at work, at leisure, through sexuality, as consumers, as minds that are curious and seek to be entertained, as social subjects that are knowing and have an interest in the way society is organized.

From the outlines of Marxism and Freudian psychoanalysis, critical theory has expanded to various areas to include critical pedagogy, among others. Critical pedagogy involves radical examination of existing ideologies and practices of education and the need for pedagogical and social transformation to free individuals from the fetters of consumer capitalism and to help make possible a free, more democratic and human culture and society. In addition to its focus on personal liberation through the development of critical consciousness, critical pedagogy also has a more collective political component, in that critical consciousness is positioned as the necessary first step of a larger collective political struggle to challenge and transform oppressive social conditions and to create a more egalitarian society. ${ }^{2}$

In my search for texts that could interpret the critical theory tradition in terms congenial to critical pedagogy, I recently began to re-read the work of Erich Fromm. Perhaps precisely because of his accessibility, Fromm has not enjoyed the same critical acclaim as his contemporaries, sometimes being regarded as "Frankfurt elite." As a self-proclaimed social psychologist, Fromm emphasized the psychology of the individual as much as political critique. But

2 Ira Shor defines critical pedagogy as "[h]abits of thought, reading, writing, and speaking which go beneath surface meaning, first impressions, dominant myths, official pronouncements, traditional clichés, received wisdom, and mere opinions, to understand the deep meaning, root causes, social context, ideology, and personal consequences of any action, event, object, process, organization, experience, text, subject matter, policy, mass media, or discourse." Empowering Education: Critical Teaching for Social Change (Chicago: Chicago University Press, 1992), 129

On the other hand, for Paulo Freire, who is arguably the most celebrated critical educator, critical pedagogy involves subverting the Hegelian master/slave dialectic, in which oppressed individuals undertake a transformation from object to subject, and thus properly become a subject and more fully developed human beings. Responding to the situation of colonization and oppression, Freire's pedagogy of the oppressed involved a type of decolonization, a consciousness-raising, and allowed the educated the right to thematize issues of study, to engage in dialogue with teachers, and to fully participate in the educational process. Pedagogy of the Oppressed, trans. by Myra Bergman Ramos, $30^{\text {th }}$ ed. (New York: Continnum, 2000), 43. 


\section{R. PANGILINAN}

3

his analysis always insisted that both psychological and socio-political understandings needed to co-exist if contemporary life were to be fully understood. Books such as The Art of Loving exhibit a tone and terminology that make them congenial reading for educators and theoreticians influenced by American, rather than European, intellectual traditions. ${ }^{3}$ Fromm strove constantly for an accessibility and consistency of language, interpreting ideas drawn from the critical tradition in terms comprehensible to the average reader. His comment in the foreword to The Art of Loving that "to avoid unnecessary complications I have tried to deal with the problem in a language which is non technical (sic) as far as this is possible"4 could apply to most of his work. As a consequence, his books have been read by millions who would be very suspicious of opening texts such as Antonio Gramsci's Selections from the Prison Notebooks, Karl Marx and Friedrich Engels' The German Ideology, or Louis Althusser's Lenin and Philosophy and Other Essays.

I will argue that this congeniality of tone makes Fromm's work a statement of critical theory that is particularly accessible to readers. His work is potentially important for educators trying to build a case for taking this body of work more seriously. Critical theory should not be constrained within gatherings of academic scholars and researchers, while the wider field of practice honors self-actualization and human capital theory, i.e., a theoretical framework for the wholesome adoption of education and development policies for the expansion of a person's stock of competences, knowledge and personality attributes leading to a more effective participation in the labor force. ${ }^{5}$ Inasmuch as Fromm can write in terms acceptable to a chiefly nonpolitical audience, and that he can do this while unapologetically showing how this work is grounded in a Marxist-influenced critique of capitalism, it makes him particularly important to the critical-theory tradition in critical pedagogy. Fromm undertook a powerful Marxist analysis of life and learning, drawing consistently and explicitly on concepts of commodification, objectification, and alienation, yet managed to conduct this analysis in a very accessible way that ensured his words were read by millions. It was not so much that he developed startling new theoretical constructs (though I believe he articulated the phenomenon of automaton conformity with a particularly American twist) but that he managed to illuminate the forms of alienation produced by capitalism in a manner understandable to most readers. Moreover, his plan for

\footnotetext{
${ }^{3}$ Erich Fromm, The Art of Loving: An Enquiry into the Nature of Love (New York: Harper \& Row, 1956)

${ }^{4}$ Ibid., vii.

5 D.A. Olaniyan and T. Okemakinde explain that human capital theory emphasizes how education increases the productivity and efficiency of workers by increasing the level of cognitive stock of economically productive human capability which is a product of innate abilities and investment in human beings. The provision of formal education is seen as a productive investment in human capital, which is equally or even more equally worthwhile than that of physical capital. They argue that an educated population is a productive population. "Human Capital Theory: Implications for Educational Development," in European Journal of Scientific Research, 24:2 (December 2008), 157-162, <http://www.eurojournals.com/ejsr 24_2 01. pdf>, 6 February 2010.
} 


\section{AGAINST ALIENATION}

the overcoming of alienation through the teaching of a structuralized worldview and the creation of a network of dialogic groups to further participatory democracy constitute two important education projects. In the following paragraphs, I shall expatiate Fromm's analysis of alienation under capitalism and review the educational responses he suggested to counter this.

\section{Fromm as Radical Humanist}

Of all the theorists associated with the Frankfurt School, Fromm is probably the one who in his time was read by the largest number of readers, including many non-Marxists well outside the critical tradition. Why should this be the case? Perhaps one reason is that he frequently described his commitment to radical humanism. His theory is humanist in the sense that it operates from an explicitly humanistic ethics, and radical in the sense that it requires a wholesale transformation in social relations. In Man for Himself, he anticipated his later radical humanist and utopian propensities when he wrote in a footnote that "Utopias are visions of ends before the realization of means, yet they are not meaningless; on the contrary, some have contributed greatly to the progress of thought, not to speak of what they have meant to uphold faith in the future of man." 6 In this book, Fromm also noted that twentieth-century intellectual culture is devoid of visions of a better humanity; the emphasis has been on critical studies of man and society. While readily conceding that such a critical attitude is very important for the development of society, he pointed out that the absence of utopian visions "has had the effect of paralyzing man's faith in himself and his future."7

Fromm saw two alternative roads for humanity: the destruction of the human race or the dawn of a new era, which would be ushered in by the vanguard of new radical humanism. He insinuated that a failure to adopt the principles of radical humanism could mean the end of the world, no less. Thus, there was much at stake in his proposal for a new kind of socialism. In the preface to Socialist Humanism: An International Symposium, he defines humanism as the "belief in the unity of the human race and man's potential to perfect himself by his own efforts" and adds that "all humanists have shared a belief in the possibility of man's perfectibility." Fromm's idea of the perfectibility of the human species is at the root of Western utopianism, and his radical humanism is an exemplary representative of social dreaming for he was inspired by the utopian desire to transform alienated people into living people. Building a new society on the principles of radical humanism would mean the "end of "humanoid" history, the phase in which man has not yet become fully human."

${ }^{6}$ Erich Fromm, Man for Himself: An Inquiry into the Psychology of Ethics (London: Routledge, 2003), 30.

${ }^{7}$ Ibid., 83.

${ }^{8}$ Erich Fromm, ed., "Introduction," in Socialist Humanism: An International Symposium (New York: Allen Lane the Penguin Press, 1965), ix.

${ }^{9}$ Ibid., "The Present Human Condition," 103. 


\section{R. PANGILINAN}

He envisioned the emergence of the naturally benevolent 'One Man,' someone who "transcends the narrow limits of his nation and who experiences every human being as a neighbor, rather than as a barbarian; a man who feels at home in the world." 10 He put great emphasis on the psycho-utopian idea of inner transformation, for he believed that the Age of Man, the renaissance of humanism, can come into being only if a New Man comes into being. An inner transformation is therefore a prerequisite for the transformation of society. Here Fromm revised the utopian aspect of Marxism by downplaying Marx's deterministic account of consciousness, suggesting that a change of consciousness precedes a change of society.

Like radical utopian authors, and unlike Marxist historical materialists, Fromm did not put his faith in history, which would lead humanity into freedom and bring about the natural goodness of human beings. Rather than being a socio-economic determinist, he nurtured the Messianic-utopian hope that the inner transformation of humans would usher in a new era, and he contended that the precondition for the improvement of the human condition is not that there occur changes in the socio-economic sphere but that people become aware of their true needs and true values. Only after the breakthrough of such awareness will it be possible to make drastic changes in social arrangements (such as the abolishment of an intrinsically authoritarian patriarchal society or the introduction of a structuralized worldview in education).

True enough, Fromm wanted to develop the radical humanist project of Marx and update it with the help of psychoanalysis. He considered psychoanalysis as indispensable for illuminating the phenomenon of alienation, which for him was a psychological experience and as such had to be examined in the context of narcissism, depression, fanaticism, and idolatry. ${ }^{11}$ His radical humanism aspired to synthesize humanistically-oriented psychoanalysis (i.e. Fromm's psychoanalysis) and genuine (i.e. humanist) Marxist theory.

Apparently also, he did not interpret history in terms of Marxist dialectics, which would have provided him with a neat conceptual scheme with the help of which he could have seen the renaissance of humanism as the dialectical negation of the anti-humanist socialist tradition of the twentieth century. He did not seem to have any interest in the finer nuances of dialectical materialism or in Marx's economical analyses of capitalism. Unlike many European intellectuals, he preferred clarity of thinking and lucidity of writing style to opaque theorizing, and he did not respect the often abstruse jargon that characterizes continental philosophy.

A humanistic perspective on education is usually interpreted as one that emphasizes respect for each learner's individuality and that seeks to help the individual realize her or his potential to the fullest extent possible. There is little attention to the political underpinnings of education practice and to the

\footnotetext{
${ }^{10}$ Erich Fromm, Beyond the Chains of Illusions: My Encounter with Freud and Marx (New York: Continuum, 2003), 162.

11 Cf. Erich Fromm, "The Application of Humanist Psychoanalysis to Marx's Theory," in Socialist Humanism, 228-45.
} 


\section{AGAINST ALIENATION}

way political economy makes self-actualization a luxury for a certain social class. In contrast to this, Fromm's normative humanism is a militant, Marxist humanism, one that contends that each human's realization of potential entails the abolition of capitalist alienation and the creation of democratic socialism. But because they are called humanist, Fromm's ideas beckon enticingly to scholars who would not dream of touching anything remotely considered Marxist.

So, despite the accessibility of his writing, Fromm's essential radicalism needs to be recognized. It should be made explicit that his analysis of contemporary society and his belief in education as crucial to a sane society are grounded explicitly in a Marxist analysis of capitalism, particularly the alienated nature of work and learning. Working firmly within the "ideology as false consciousness" perspective, Fromm observed that through "a complicated process of indoctrination, rewards, punishments, and fitting ideology . . . most people believe they are following their own will and are unaware that their will itself is conditioned and manipulated." 12 For him, learning to penetrate ideological obfuscation, and thereby overcoming the alienation this obfuscation induced, was the learning task of adulthood.

Fromm clearly saw a direct link between a healthy society free from capitalist alienation and a strong system of education. In his major book interpreting Marxism for a popular audience, he wrote that "a sane society must provide possibilities for education, much as it provides today for the schooling of children."13 Education as a force for resistance to false consciousness would make people aware of ideological manipulation and educate them for participatory democracy. In such a democracy, he claimed, people "regain control over the social and economic system" to make "optimal human development and not maximal production the criterion for all planning." 14 If people were to understand and confront their alienation, they needed to understand how history and psychology intersected to construct a social character prone to follow fascist or totalitarian leaders and subject to the influence of automaton conformity. The difficulties entailed in this form of learning could not be overcome by children or adolescents. In Fromm's opinion, "To really understand the problems in these fields, a person must have had a great deal more experience in living than he has had at college age. For many people the age of 30 or 40 is much more appropriate for learning." 15

\footnotetext{
12 Erich Fromm, To Have or To Be? (New York: Harper \& Row, 1976), 83.

${ }_{13}$ Erich Fromm, The Sane Society (New York: Holt, Rinehart and Winston, 1955), 346.

${ }^{14}$ Erich Fromm, The Revolution of Hope: Toward a Humanized Technology (New York: Harper \& Row, 1974), 101

${ }^{15}$ Fromm, The Sane Society, 346.
} 


\section{R. PANGILINAN}

\section{Fromm's Debt to Marx: Commodification, Objectification and Alienation}

The Marxist concepts of commodification, objectification and alienation surface again and again in Fromm's work, constantly underpinning his own normative humanism. Commodification is the transformation of relationships, formerly untainted by commerce, into relationships of exchange. It takes place when economic value is assigned to something not previously considered in economic terms, or in other words, the expansion of market trade to previously non-market areas, and to the treatment of things as if they were a tradable commodity. Human beings can be considered subject to commodification in contexts such as genetic engineering, social engineering, cloning, eugenics, mass marketing and employment. An extreme case of commodification is slavery, where human beings themselves become a commodity to be sold and bought. Similarly, the use of animals for food, clothing, entertainment, or testing represents the commodification of other living beings.

Objectification is the manifestation of human activity into a materially existing form. It is also termed as reification, the consideration of an abstraction, relation or object as if they had human or living existence and abilities, when in reality they don't; it implies the thingification of social relations. A person, for instance, makes something and the product of his labor thereby expresses his personality and the social relations in which the labor was carried out. Marx argues that objectification is an inherent and necessary characteristic of economic value as it manifests itself in market trade, i.e. the inversion in thought between object and subject, or between means and ends, reflects a real practice where attributes (properties, characteristics, features, powers) which exist only by virtue of a social relationship between people are treated as if they are the inherent, natural characteristics of things, or vice versa. ${ }^{16}$

Objectification needs to be contrasted with alienation, which refers to objectification under conditions when the product of a person's labor not only becomes objective to them, but foreign. For Marx, the social relations of capitalism alienate human beings from the world around them: from their products, their work, their fellow workers and their species being. The concept

16 The reifying nature of economic relations in capitalist societies is expressed by Marx thus: "The production of capitalists and wage-laborers is therefore a major product of the process by which capital turns itself into values. Ordinary political economy, which concentrates only on the objects produced, forgets this entirely. Inasmuch as this process establishes reified labor as what is simultaneously the non-reification of the laborer, as the reification of a subjectivity opposed to the laborer, as the property of someone else's will, capital is necessarily also a capitalist. The idea of some socialists, that we need capital but not capitalists, is completely false. The concept of capital implies that the objective conditions of labor-and these are its own product-acquire a personality as against labor, or what amounts to the same thing, that they are established as the property of a personality other than the worker's." Karl Marx, Grundrisse: Foundations of the Critique of Political Economy, trans. by Martin Nicolaus (New York: Penguin, 1973), 514-515. 


\section{AGAINST ALIENATION}

of alienation for Marx expressed the separation of individuals from what gives a human life meaning: actions in the world that makes that world his. Because labor under capitalism is external to the worker-is not part of his essential being-"'he does not confirm himself in his work, but denies himself, feels miserable and not happy, does not develop free mental and physical energy, but mortifies his flesh and ruins his mind." ${ }^{, 17}$ It is a system of belief, i.e., political economy, that sustains the social system of capitalism just as religions have sustained the ideological power of shamanistic classes and belief in the specialness of royal bloodlines have sustained monarchies. Political economy as a system of ideas that locates economic value in commodities (objects, goods and services) independent of the human work that went into creating them is subject to critique by Marx as the fetishism of commodities. By treating the commodity as something alienated from humans in the process of its production, political economy then reappropriates it as an idea, an abstraction, as something that has intrinsic value that transcends sensuousness. The commodity takes on a mystical character in which its properties appear as natural when they are in fact the result of the human labor that produced them (objectification). The relations between objects, i.e., their relative exchange values, appear to be just as independent of human labor as do the powers of fetishes. Goods do have a use value in the lives of people, but this is obscured in the process of commodity exchange (commodification). Marx argues that bourgeois economics began with the analysis of price and took money to be the expression of value: "It is however precisely this finished form of the world of commodities, i.e., the money form, which conceals the social character of private labor and the social relations between individual labor, by making those relations appear as relations between material objects, instead of revealing them plainly."18

It is not amiss to note that Theodor Adorno employed these Marxist conceptual resources in critiquing culture and art earlier than Fromm did, and it is to this that I briefly turn. Adorno argued that in advanced capitalist societies, the culture industry produces material that deadens the masses, while the potential of art to provoke critical thought is drowned by the peddling of endlessly bland and repetitive cultural commodities. Just as manufacturing industry generates things as products, so the culture industry generates and circulates ideas as products. As with commodity production in general, the social form fetishises cultural products, creating specific cultural and economic value in intangible commodities such as the entertainment value of a film or the artistic value of a painting. ${ }^{19}$ The culture industry results from the penetration of the organization and business practices of industrial capitalism into the sphere of culture early in the twentieth century. Cultural commodities

\footnotetext{
${ }^{17}$ Karl Marx, Early Writings, trans. by Rodney Livingstone and Gregor Benton (New York: Vintage Books, 1975), 326.

${ }^{18}$ Karl Marx, Capital: A Critique of Political Economy, trans. by Ben Fowkes (London: Penguin, 1976), vol. 1, 168-169.

19 Theodor Adorno, The Culture Industry: Selected Essays on Mass Culture, ed. by J.M. Bernstein (London: Routledge, 1991), 33-35.
} 


\section{R. PANGILINAN}

are directed not to the material needs of human beings, such as food and clothing, but to people's minds, i.e., their conscious and subconscious selves. Capitalism has an interest in the state of those minds: it needs workers who are happy enough to accept uncritically their position within the system.

The chief outlines of Fromm's critique of contemporary society-and, by implication, of education-are drawn directly from Marxist thought, particularly Marx's outline of the way in which work in capitalist society has become objectified, that is, experienced by workers as separated from their creativity and identity. In 1961, Fromm published Marx's Concept of Man, a translation of Marx's Economic and Philosophic Manuscripts, along with his own interpretive commentary. The first manuscript translated is "Alienated Labor," Marx's classic statement on the way in which capitalist economics means that "the individual worker sinks to the level of a commodity, and to a most miserable commodity." ${ }^{20}$ In this essay, Marx described the development of monopoly capitalism and the decline of the individual entrepreneur. In capitalist economies, "the necessary result of competition is the accumulation of capital in a few hands," a development Marx viewed as "a restoration of monopoly in a more terrible form.",21

The injuries of monopoly capitalism surface repeatedly in Fromm's work. In The Art of Loving he writes that under modern capitalism "we witness an ever-increasing process of centralization and concentration of capital" in which "the ownership of capital invested in these enterprises is more and more separated from the function of managing them." ${ }^{22}$ When the owners of capital can command labor to produce goods that increase the return on the owner's investment, then a hierarchy emerges in which "amassed things, that which is dead, are of superior value to labor, to human powers, to that which is alive." ${ }^{23}$ Work under such a system is physically exhausting, mentally debasing, and creatively moribund. Because people work for someone else, their labor becomes converted into someone else's property. Although the end product is the creative work of the laborer he could not fully identify with the object since the hypostatization of the market system reduces the laborer-product relation into reified market value. The laborer is alienated from his own work because he totally loses control of the product as it is submitted to the market system.

Using Fromm's analysis as a starting point, it is quite possible to interpret learning processes through the lens of objectification. In mandatory continuing education, compulsory training, and the required participation of employees in human resource development programs, it is easy to see how learning undertaken to satisfy external authorities, such as employers, ceases to become the learner's intellectual project. Employees often press themselves to take further studies on top of their undergraduate degree for the purpose of

${ }^{20}$ Erich Fromm, Marx's Concept of Man, with a translation of Marx's Economic and Philosophic Manuscripts by T.B. Bottomore (London: Continuum, 2004), 93.

${ }^{21}$ Ibid.

${ }^{22}$ Fromm, The Art of Loving, 84.

${ }^{23}$ Ibid. 
getting a promotion and receiving a higher remuneration. Very frequently also, the products and measures of learning-essays, test scores, papers, examstake on physical form and stand apart from the learner. The exam does not measure the person's engagement in creative work that confirms her or his identity but rather exerts a coercive pressure requiring the learner to improve her or his performance according to criteria she or he has no chance of affecting.

When labor is objectified, something peculiar happens to the worker's emotions: "The more the worker expends himself in work, the more powerful becomes the world of objects which he creates in face of himself, the poorer he becomes in his inner life, and the less he belongs to himself." ${ }^{24}$ Initially, capital brings together workers who were previously isolated independent workers or small masters. The worker then strips off the fetters of his individuality, and develops the capabilities of his species. That being the case, argues Marx, prior to the capitalization of production workers do lack a social identity. However, once they are subsumed beneath capital their productive powers acquire a social guise no longer reducible to their individual efforts. However, this would mean that the more labor is socialized by capital the more the capacities of workers become the attributes of capital. "These things are not their own act, but the act of the capital that brings them together and maintains them in that situation . . . who subjects their activity to his purpose." ${ }^{, 25}$ Capital brings about division of labor in which the labor process is divided into smaller and simpler tasks each allocated to individuals or groups of workers. The resulting series of repetitive and mindless tasks reduces workers, in Marx's graphic phrase, to crippled monstrosities. Finally, science and technology are applied to production to create an industrial revolution. Workers lose the last remnants of control they retained over the labor process and become mere living appendages of the machine. This completes the transformation of workers into mere means for the objective ends of capital. Thus, according to Marx, "it is only with the coming of machinery that this inversion first acquires a technical and palpable reality." 26 The social powers of labor are rendered identical with the social powers of capital and the former ceases to exist as an independent activity.

In commenting on Marx, Fromm argued that Marxism was less a political creed, more a "spiritual existentialism" in secular language. Fromm provocatively writes: "Marx's aim, socialism, based on his theory of man, is essentially prophetic Messianism in the language of the nineteenth century."27 It is spiritual existentialism because for Fromm Marx's aim was that of the spiritual emancipation of man, of his liberation from the chains of economic determinism, of restituting him in his human wholeness, of enabling him to find unity and harmony with his fellow man and with nature. Marx, Fromm

\footnotetext{
${ }^{24}$ Marx quoted in Marx's Concept of Man, 96

${ }^{25}$ Marx, Capital, vol. 1, 450.

${ }^{26}$ Ibid., 548.

${ }^{27}$ Fromm, Marx's Concept of Man, 5.
} 
believed, was not concerned primarily with equalizing income. His main interest was in stopping labor from being an alienating experience. In commodity-determined society, labor as an activity becomes the commodity labor power when the form of private property develops into a series of social relations entailed in the accumulation of capital and its investment in production. One's product, then, serves someone else as a good, a use value; it serves the producer as the means of acquiring the labor products of others. This signifies that one's labor has a dual function: on the one hand, it is a specific form of labor that produces particular goods for others, yet, on the other hand, labor independent of its specific content serves the producer as the means by which the products of others are acquired. Labor, then, is an alienating experience because the specificity of the producer's labor is alienated from the products they acquire with their labor. There is no intrinsic relation between the specific nature of the labor expended and the specific nature of the product acquired by means of that labor. Fromm quotes Marx's comments in volume 1 of Capital that methods of production under capitalism mutilate the laborer into a fragment of a man, degrade him to the level of an appendage of a machine, destroy every remnant of charm in his work and turn it into a hated toil. So for Fromm, Marx's central criticism of capitalism is not the injustice in the distribution of wealth; it is the perversion of labor into forced, alienated, meaningless labor.

In fact, Fromm's analysis of alienation deepened and broadened Marx's initial exposition of the idea. Fromm contended that Marx underestimated the intensity and pervasiveness of alienation that had become the fate of the vast majority of people, especially of the ever increasing segment of the population which manipulate symbols and men, rather than machines. In contemporary society, people "worship things, the machines which produce things - and in this alienated world they feel as strangers and quite alone." ${ }^{28}$ In such works as Escape from Freedom ${ }^{29}$, Man for Himself, and The Sane Society, Fromm illustrated the power of the concept of alienation, extending it from the world of work into the domains of politics, recreation, and intimate relationships. Commodification has distorted even our language to the point that our speech style indicates the prevailing high degree of alienation we feel. Fromm asked us to consider the colloquial phrase "I have a problem" and the commodification this signifies: "by saying 'I have' a problem instead of 'I am troubled,' subjective experience is eliminated; the $I$ of experience is replaced by the it of possession . . . I have transformed myself into 'a problem' and am now owned by my creation." 30 This commodification of language further

\footnotetext{
${ }^{28}$ Ibid., 57.

${ }^{29}$ Erich Fromm, Escape from Freedom, 4th ed. (New York: Avon Books, 1966).

30 To Have or to Be? 31. The consequences of the universally accepted "to have" (as opposed to "to be") philosophy are, in Fromm's opinion, just as profound as vividly negative. The practice of this attitude influences to a great degree the reification and depersonalization of all interpersonal relations. The "to have" standpoint comprises an "axiological infrastructure" of the technological subjugation of Nature by man. It inclines him to treat Nature as the object of a conquest, a tendency which could produce a global ecological crisis and the danger of the
} 


\section{AGAINST ALIENATION}

ensures that in all aspects of modern life one experiences oneself as a commodity or, rather, simultaneously as the seller and the commodity to be sold.

As a counter to alienation, Fromm proposed a version of socialism that he called humanistic or communitarian socialism. This kind of socialism did not stress the equalization of income or distribution of profits. Its emphasis was on the creation of a workplace in which workers controlled the pace and form of production. Instead of being separated from each other and denied the opportunity to exercise their own creative energies, workers in a socialist system experienced work as an associative and creative activity. $\mathrm{He}$ traced this version of socialism to what he claimed were the humanistic underpinnings of Marx's version of socialism. Fromm wrote that "the principal goal of socialism for Marx is the recognition and realization of man's true needs, which will be possible only when production serves man and capital ceases to create and exploit the false needs of man." ${ }^{31}$ To Fromm, socialism is more about human creativity than economic arrangements. It is "a form of production and an organization of society in which man can overcome alienation from his product, from his work, from his fellow man, from himself and from nature. ${ }^{32}$ A socialist society is one in which people feel connected to each other, able to discover and exercise their own creative impulses, and aware of their relationship to the natural environment. In such a society, a person will be able to return to himself and grasp the world with his own powers thus becoming one with the world.

As a follower of communitarian socialism, Fromm outlines a progressive political strategy which promotes a radical change of values away from instrumentality, possessiveness and acquisitiveness and towards social responsibility and respect for people. The social action which aids this change includes both old and new social movements, the struggle for reforms as well as direct protest. For example, Fromm endorsed the significance of trade union activity in struggling for worker participation in management and the reduction of working hours, as well as day-to-day struggles on issues such as discrimination and bullying. He was one of the first social theorists to identify the radical potential of new social movements, particularly those concerned with environmentalism and feminism. He lent support to reforms which eradicate the causes of insecurity which too often push people to reactionary

exhaustion of natural resources. It also contains the peril of international conflicts with global implications. In his other books (e.g. Zen Buddhism and Psychoanalysis) Fromm had in mind phenomena similar to the "to have" stand, and wrote about the domination or the alienation of manipulative human intelligence from the control of the intellect, which indicated and controls suitable, from the ethical viewpoint, targets of activity. The "to have" standpoint is also linked with the conception of the marketing personality, whose outline was presented in Man for Himself within the context of reflections about productive and unproductive orientations, as well as in reference to Escape from Freedom, where, by basing himself on observations of the American society, Fromm analyzed the phenomenon of mechanical or automaton conformism.

31 Fromm, Marx's Concept of Man, 59.

32 Ibid. 
responses or to despair. He identified the emergence of the 'One World"33 in an era of globalization which begs for global political solutions to the problems of war and peace, production and distribution, and sustainability. Ultimately, Fromm held fast to the idea that socialism is the only political movement which has the capacity to retain the hope of human liberation, the establishment of new moral values, and the realization of human solidarity. But he recognized the weaknesses of previous forms of socialism, particularly in neglecting the visualization of a better world. In calling for the proliferation of designs, studies and experiments to bridge the gap between what is necessary and what is possible, he insisted that the model of the new society be determined by the requirements of the un-alienated, being-oriented individual. In raising this 'big' questions of why we live the way we do and how we might live differently and better, Fromm's work resolutely opposes the creeping fatalism of contemporary social and political life.

Now it is not an enormous stretch to see in Fromm's vision of communitarian socialism a larger vision of the processes that would be observable in education classrooms striving to realize some principles of participatory democracy. In such classrooms, the object would be to make education serve the true needs of learners instead of satisfying their false needs. False needs will be those that uncritically mimic the aspirations of the dominant culture such as learning to compete more effectively against other learners, learning skills that allow people to acquire more and more possessions they do not really need, or learning how to adapt one's thinking and behavior to prevailing mores and cultural patterns. In seeking to overcome the individual alienation from learning and from her or his fellow learners, a classroom would emphasize cooperative ways of working. It would regard the individual pursuit of truth, beauty, and knowledge as the exception to the collaborative rule. Education as communitarian socialism would be dialogical, an attempt to create a continuous conversation among learners in which all voices would be heard equally.

It is because of their suspicion of how learning can become objectified and experienced by persons as hostile to their real needs and inner yearnings that so many educators have stressed, and continue to insist on, the voluntary

33 The principal ideological obstacle to the development of a harmonious global society, that is, One World, in Fromm's view is tribalism, a feeling that we have the confidence only in those who belong to our tribe (or in-group such as a nation or race). Nationalism is the modern form of tribalism, through which we project all the evil in us on the stranger, and in so doing we lose touch with humanity. As part of his personal 'Credo' appended to Beyond the Chains of Illusions, he expressed his belief that the One World will become truly human only if a 'New Man' comes into being, free of tribal loyalties, beyond the call of blood and soil, who feels himself to be a "citizen of the world whose loyalty is to the human race and to life." Beyond the Chains of Illusions, 178 . He also argues that human solidarity can be found only when nationalism has been transcended; only when we develop our love and reason further than we have done so far can we "build a world based on human solidarity and justice" and thereby transform it into "a truly human home." The Sane Society, 60. 
underpinnings of genuine education. From Lindeman ${ }^{34}$ to $\operatorname{Horton}^{35}$, a school of education has contended that education only happens when persons opt voluntarily for a program of learning they have designed. This tradition regards mandatory education as an oxymoron. It focuses instead on how education can help learners develop skills and knowledge that will help them understand and change the communities in which they live. This learning happens through a collaborative analysis of persons' experiences during which the roles of teacher and learner move among participants. Education formats attempt to replicate the best features of participatory democracy, with all participants actively involved in deciding aspects of what and how to learn.

\section{The Alienation Character of Capitalism}

As mentioned above, alienation is Fromm's key term in much of his works. As a psychoanalyst, he believed that alienation is a pathological state of mind that must be studied empirically by dynamic psychology. When he sketches the genealogy of this concept, he goes as far back as the Old Testament prophets, who referred to the polytheistic worship of idols as idolatry. In the early modern world, alienation was used to denote mental disorder, and, says Fromm, Hegel and Marx used the term to illustrate selfestrangement. ${ }^{36}$ Fromm had picked the term from the young Marx, who used it to criticize the inability of bourgeois society to satisfy the needs of its citizens, especially but not exclusively the needs of the proletariat. Alienation is, however, a necessary stage in the process of self-realization, which Marx-in contrast to the German idealist philosophers-saw in materialist terms as an outcome of man's own labor. Alienation, which for Marx is always selfalienation, prevents humans from developing their inherent morality and hence from adapting their lives to their true nature. In the mature Marx, the term plays only a minor role, but Fromm was mainly inspired by the young Marx's so-called Paris Manuscripts (Economic and Philosophical Manuscripts of 1844).

${ }^{34}$ Eduard Lindeman, The Meaning of Adult Education (Buffalo: Harvest House, 1961). Adult education is the practice of teaching and educating adults. This often happens in the workplace, through 'extension' or 'continuing education' courses at secondary schools, at a college or university. Other learning places include folk high schools, community colleges, and lifelong learning centers. The practice is also often referred to as 'Training and Development' and andragogy (to distinguish it from pedagogy). A difference is made between vocational education, mostly undertaken in workplaces and frequently related to upskilling, and non-formal adult education including learning skills or learning for personal development.

35 Myles Horton, The Long Haul: An Autobiography (New York: Doubleday, 1990). Horton founded the Highlander School and became the first practitioner of what would later be called popular education. Highlander used the principles of democratic education-where students were the authorities in the classroom, the teacher is a facilitator, and the focus of education is teaching collective action for social change-to play a key role in the labor movement of the 1930s and the Civil Rights movement of the 1960s to 1970s. Horton also pioneered many of the educational principles Paulo Freire would make famous worldwide in the 1980s.

${ }^{36}$ Fromm, The Sane Society, 121. 
While he draws on these earlier understandings of alienation, as a psychoanalyst, Fromm ultimately defines alienation in medical terms and suggests that "the insane person is the absolutely alienated person" ${ }^{, 37}$ who has lost a sense of self and cannot situate him/herself as the center of his/her own experiences. He suggests that as people become alienated, they lose their dignity and their understanding of themselves and do not see their experiences as being based on their own decisions, judgments, and actions. Rather than existing as unique productive individuals able to use reason to relate to the world, alienated people crave approval from others and fear being considered different because they see it as a danger that threatens their sense of security. Alienated people lead meaningless lives; they are estranged from themselves, others, and society. Fromm considers alienation almost complete in modern capitalist societies, and explains that it pervades individuals' consumption habits as well as their relationships to their work, to their communities, to their fellow citizens, and to themselves. An alienated person lacks a sense of reality regarding "the meaning of life and death, for happiness and suffering, for feeling and serious thought." ${ }^{38}$ In a technological age, machines routinely replace human intelligence and citizens tend to manipulate symbols and other people rather than actively and creatively producing commodities. They are not invested in their work, and find it routine, boring, and dull, which further contributes to a sense of apathy and dissatisfaction with their lives. As Fromm explains, in contemporary society work often can be defined "as the performance of acts which cannot yet be performed by machines." 39 Within alienated societies consumption is seen as both an individual's right and duty, creating an "orgy of consumption [that] dominates our leisure hours and fills our dreams of heaven." 40 Individuals are consumption-hungry, receiving pleasure from the purchases they make rather than from the actual use of what they buy. Fromm insists that consumption now dominates and defines the culture of democratic capitalist societies. Citizens consume food, drink, news, and entertainment without any active participation or unifying experiences resulting from the consumption. In addition, a continuous, ever expanding need for consumption is encouraged by "artificially stimulated fantasies" 41 created by advertising and a variety of other psychological pressures that coax individuals into repeatedly buying as much as they can.

In its vagueness, alienation is an exemplary representative of German idealism, but it has suggestive force not unlike the Freudian term the unconscious or the Foucauldian term power; they all function like magic words that ostensibly reveal an essential but hard-to-pin-down component of human psychology and social order. In the 1950s and the 1960s, the notion of

\footnotetext{
${ }^{37}$ Ibid., 124.

38 Ibid., 171

${ }^{39}$ Ibid., 180.

40 John Schaar, Escape from Authority: The Perspectives of Erich Fromm (New York: Basic Books, 1961), 196.

${ }^{41}$ Fromm, The Sane Society, 134.
} 


\section{AGAINST ALIENATION}

alienation appealed to such diverse thinkers as existentialists, psychologists, literary critics, non-Communist Marxists (such as Fromm) and Christian and Jewish theologians. As David Coute observes in his analysis of two types of alienation, alienation fulfills "in modern ideology the same function as the Fall in Christian mythology." 42 It seems it was an important term for the intellectuals, who prided themselves on the alleged fact that they had privileged insight into socio-cultural processes and/or the functioning of the unconscious, and that their acute awareness of the inadequate and corrupt state of society alienated them from the established (false) value system.

In The Sane Society, Fromm gives a sweeping historical overview of the conditions that have made people alienated. As a true Marxist (but unlike Marx himself), he puts the blame on capitalism as it evolved from the seventeenth to the twentieth century and sees the United States as the capitalist model towards which other Western countries are developing. Through the economic processes of quantification and abstractification, the United States has produced a new type of human being, a person whose main duty is to spend and to consume (and not to hoard), to be flexible (and not commit oneself to objective moral principles), and to co-operate smoothly in large groups as a $\operatorname{cog}$ in the machine (instead of being self-employed or working in a close personal contact with fellow humans). The capitalist system of mass production requires a social character driven by self-interest, opportunism and conformism. As a result, the contemporary social character in the West tends to be devoid of altruistic impulses, solidarity and an understanding of itself as an active agent. The modern individual in a capitalist society, driven by marketing orientation, has become a thing, a mere commodity. The potential end result of total alienation, exemplified in the extreme form of marketing orientation, is the fall of civilization and the end of the human race. Thus, there is much at stake in the phenomenon of alienation.

Fromm views the distinguishing character of capitalism as the elevation, to practically the exclusion of all else, of the economic domain of life. Its leitmotif is the use of people as if they were economic objects: "the owner of capital uses other men for the purpose of his own profit . . . a living human being, ceases to be an end in himself, and becomes the means for the economic interests of another man, or himself, or of an impersonal giant, the economic machine." 43

A necessary corollary of assessing human worth in economic terms is the elevation of materialistic values over human values of compassion, skill, or creativity. Thus, "in the capitalistic hierarchy of values, capital stands higher than labor, amassed things higher than the manifestations of life . . . things are higher than man." 44 Humanity is diminished as qualities such as a person's energy, skill, personality, and creativity become commodified—assets to be

\footnotetext{
${ }^{42}$ David Coute, The Illusion: An Essay on Politics, Theatre and the Novel (London: Deutsch, 1971), 172

${ }^{43}$ Fromm, The Sane Society, 93.

${ }^{44}$ Ibid., 95.
} 
sold on the market of interpersonal relations. Under capitalism, "the market decides the value of these human qualities" with the result that "relations between human beings . . . assume the character of relations between things," as each person "sells himself and feels himself to be a commodity." 45

In describing how the laws of the market corrupt personal relations, Fromm anticipates Horkheimer's irrational organization, Adorno's administered world, Marcuse's one-dimensional society and repressive tolerance and Habermas' colonization of the lifeworld, themes that have produced some provocative critiques of contemporary education. ${ }^{46}$ American "culture is based on the appetite for buying, on the idea of a mutually favorable exchange." ${ }^{47}$ Human communication and interpersonal feelings are distorted by the application of a cost-benefit analysis way of thinking to social relationships: in all social and personal relations the laws of the market are the rule. The logic of the exchange economy pervades all aspects of life, Fromm argued, because in capitalistic society the process of exchange value has become an end in itself; thus, the whole process of living is experienced analogously to the profitable investment of capital, my life and my person being the capital which is invested.

Fromm relied heavily on Marx's idea of commodity fetishism, a form of sociality in which an invisible hand regulates the economy in an autonomous fashion without conscious human intervention, ${ }^{48}$ to explain how alienation is experienced in contemporary society. In terms drawn straight from Marx's manuscript on the subject, Fromm defined alienation as "a mode of experience in which the person experiences himself as an alien . . . estranged from himself. He does not experience himself as the center of his world, as the creator of his own acts." 49 The roots of this sense of alienation lie in the nature of modern work, which requires that people pour their energy into making products that then assume an existence apart from, and over, them. In the contemporary workplace, the worker finds that his life forces have flown into a thing that becomes something apart from himself, over and against him. The worker is alienated from the object he produces because it is owned and disposed of by another, the capitalist. In all societies people use their creative

${ }^{45}$ Fromm, Escape from Freedom, 140.

46 Cf. Michael Newman, Maeler's Regard: Images of Adult Learning (Sydney: Stewart Victor, 1999) < http://www.michaelnewman.info/docs/maelers regard.pdf>, 16 March 2009); Michael Robert R. Welton, ed., In Defense of the Lifeworld: Critical Perspectives on Adult Learning (Albany: State University of New York Press, 1995). Welton takes the position that the critical theoretical tradition from Marx to Habermas can provide a foundation for an emancipatory educational practice.

${ }^{47}$ Fromm, The Sane Society, 3.

48 Karl Marx writes: "The mysterious character of the commodity-form consists therefore simply in the fact that the commodity reflects the social characteristics of men's own labor as objective characteristics of the products of labor themselves, as the socio-natural properties of these things." Capital, vol. 1, 164-165. This displacement of social relations onto material entities not only obscures the role of labor in the production of value, it also serves to endow the latter with self-animating properties.

${ }^{49}$ Ibid., 120 


\section{AGAINST ALIENATION}

abilities to produce objects which they use, exchange or sell. Under capitalism, however, this becomes an alienated activity because "the worker cannot use the things he produces to keep alive or to engage in further productive activity . . . The worker's needs, no matter how desperate, do not give him a license to lay hands on what these same hands have produced, for all his products are the property of another." 50

Fromm's extension of Marx's commodity fetishism into an analysis of rampant consumerism is still accurate half a century after it appeared. A major purpose of life in capitalism is to consume the commodities we produce, yet the experience of compulsive consumption is itself alienating. In Fromm's era and certainly pronounced today, we experience "an ever increasing need for more things, for more consumption . . . but our craving for consumption has lost all connection with the real needs of man." ${ }^{51}$ We develop what Fromm called the receptive orientation, ${ }^{52}$ in which we desire to have something new all the time, to live with a continuously open mouth as it were. Creativity, artistic expression, and personal fulfillment are equated with consuming more and more things. Fromm became positively lyrical in his description of how commodity fetishism becomes converted into the consumer ethic: "The world is one great object for our appetite, a big apple, a big bottle, a big breast; we are the sucklers, the eternally expectant ones, the hopeful ones-and the eternally disappointed ones." ${ }^{, 53}$

Education is, of course, no exception to the process of commodification. The education system generally tries to train people to have knowledge as a possession, by and large commensurate with the amount of property or social prestige they are likely to have in later life. Educational institutions give each student a certain amount of cultural property or a luxuryknowledge package with the size of each package being in accord with the person's probably social prestige. Knowledge becomes equated with content, with fixed clusters of thought, or whole theories that students store. In this system, teachers are reduced to bureaucratic dispensers of knowledge. This commodified content, transmitted bureaucratically, is alienated from persons' lives and experiences: "The students and the content of the lectures remain

50 Bertell Ollman, Marx's Conception of Man in Capitalist Society, 2nd ed. (Cambridge: Cambridge University Press, 1976), 143.

${ }^{51}$ Marx, Capital, vol. 1, 134.

52 In Fromm's humanistic psychoanalysis, receptive orientation is one of the four types of non-productive orientation (the other being exploitative, hoarding and marketing orientations), which ensue in the development of irrational passions, especially of incestuous, destructive and exploitative strivings. Receptive orientation is one where the individual is preoccupied with receiving in that he believes that the only way by which he can effect or obtain something is by getting it from outside instead of utilizing his own creative energies. A receptive individual loves to say "yes" to anybody's bidding as he is unable to elect what is good and beneficial for himself; as he is increasingly dependent on others, especially on authorities, his critical abilities therefore become stifled.

${ }^{53}$ Ibid., 166. 
strangers to each other, except that each student has become the owner of a collection of statements made by somebody else." ${ }^{, 54}$

Fromm also extended Marx's idea of commodity fetishism into the realm of political discourse, observing that the fetishism of words is as dangerous in the realm of political ideology as it is in that of religious ideology. Words have become a substitute for concrete political action, so that making a speech is considered a significant act of social change. Yet, language as a substitute for political intervention is illusory, allowing politicians the indulgence of an endless reinvention of self. Words do not change the world, deeds do. A media and politically literate person must be helped to see that words have meaning only in the total context of deed and character; unless there is unity among these factors words serve to deceive-others and oneself; instead of revealing, they have the function of hiding. In terms echoing Orwell's analysis of the perversions of political language, Fromm argued that a task of education must be to make persons aware of doublespeak, of when an utterance means exactly the opposite of what it purports to mean, as in "calling Franco and other dictators representatives of the free world. ${ }^{, 55}$

Fromm's analysis of political alienation looks back to John Stuart Mill' $s$ ideas on the tyranny of the majority and forward to the contemporary perversion of political discourse by television advertising. We are alienated politically when our political participation is reduced to our being forced to choose between candidates we had no hand in selecting and who represent mammoth parties financed by giant, yet often invisible, corporate interests. Voters are blanketed by political commercials that dull the capacity for critical thought. Not surprisingly, "this situation gives the average citizen a deep sense of powerlessness in political matters" with the result that "political intelligence is reduced more and more. ${ }^{, 56}$ Given the current widespread cynicism regarding politics, and the widespread dismissal of political commercials as propaganda, this may seem an overly pessimistic conclusion to draw. However, it is salutary to reflect on Fromm's warnings of the effects that the increasing power of monopolistic capital would have on the political process. Writing before the influence of corporate lobbyists and political action committees had become the accepted currency of politics, Fromm decried the fact that an enormous though secret power over the whole society is exercised by a small group, on the decisions of which depends the fate of a large part of society.

\section{Political Literacy and Education}

In his uncovering of elite influence within the monopoly capitalism of the media, Fromm outlined a political literacy project for education. Any

\footnotetext{
${ }^{54}$ Fromm, To Have or to Be? 37.

55 Ibid., 160; cf. George Orwell, "Politics and the English Language," in A Collection of Essays (New York: Doubleday, 1999) < http://orwell.ru/library/essays/politics/english/ e polit>, 20 March 2009.

${ }^{56}$ Fromm, The Sane Society, 191.
} 


\section{0}

AGAINST ALIENATION

socially responsible education program must include within it an attempt to lay bare the purchase by those with the most capital of access to opinion-making organizations. It must show that free speech is often bought speech, that getting one's ideas or opinions into the public sphere depends on having the capital to buy media outlets that can disseminate these ideas. Such a program would show how media must always be thought of as big businesses and how news divisions of major media outlets are heavily influenced by the interests of corporate sponsors and the need to present news in an entertaining way to keep the maximum audience. In particular, Fromm's emphasis on how an unrepresentative minority exerts disproportionate influence clearly anticipates Newman's call to name the enemy that encourages persons to retreat into abstract ideas about freedom and democracy. If, as Fromm says above, an enormous though secret power over the whole society is exercised by a small group, and if this group can exert control over political discourse out of all proportion to their size in the society, then a crucial educational task becomes to conduct appropriate research and inquiry to name the members of this group. In Newman's words, "we need to ask: who are the people, what are the organizations promoting the reorganization of capitalism? Where do they operate? Can we name them and do they have an address?" 57

Alienated politics is most tragically evident in the practice of democracy, for many people the most hopeful grand narrative of the twentyfirst century. Fromm rejected the rhetoric of democracy as liberation from tyranny, arguing instead that the democratic process had transmogrified into the tyranny of the majority. In our age of conformity, the democratic method has more and more assumed the meaning that a majority decision is necessarily right, and morally superior to that of the minority, and hence has the moral right to impose its will on the minority. He cited with scorn the advertising slogan that "Ten Million Americans Can't Be Wrong" as evidence of how the epistemic distortion of equating validity with majority opinion had spread through society. Nothing is further from the truth, Fromm argued, than to believe that agreement and consensus represent a higher epistemological authority. To him, consensual validation as such has no bearing whatsoever on reason or mental health; in fact, it is often represented as a deliberate suppression of critical thought through the exclusion of divergent opinions.

It is interesting to remember these words when we find ourselves practicing the difficult and contradictory process of trying to democratize education classrooms. Educators committed to democratic process can easily find themselves turning instinctively to the principle of majority vote when working with a group of students to decide collectively what and how to learn. Yet, as Fromm points out, the majority opinion in a classroom may stand firmly against anything that disturbs the familiarity of teacher authority, didactic transmission of information, and curriculum being decided by omniscient

${ }^{57}$ Michael Newman, Defining the Enemy: Social Action in Adult Education (Sydney: Stewart Victor, 1994) < http://www.michaelnewman.info/docs/defining the enemy.pdf $>$, 16 March 2009, 149. 
strangers in far-off places. As Shor illustrated, a majority of students will usually choose not to rock the boat by challenging conventional thinking on race, class, or gender, or by opting to explore political dynamics outside, but especially inside, the classroom. Her study of a writing class for students shows how an apparent act of resistance-asking students to take a measure of control in choosing what to learn-can end up reproducing dominant ideology. Her students chose to avoid contentious racial issues and to stay close to home with familiar topics. ${ }^{58}$

Here is one of the unresolvable tensions of critical practice: how to respect the agendas people bring to a democratic negotiation of curriculum while contradictorily challenging these agendas by offering (and sometimes insisting on) radically different, politically contentious options for study. As Fromm argued, if educators stop short of insisting on some attention being paid to alternative, minority viewpoints, then the process of automaton conformity, of choosing to think and do what one supposes everyone else thinks and does, runs rampant. A deliberate suppression of alternative perspectives in the name of a democratic honoring of the people's will was one of the chief indicators that automaton conformity was in place and unchallenged.

\section{Alienation as Automaton Conformity}

Alienation as a pervasive mode of existence was most evident in the phenomenon of automaton conformity. This idea is explained most fully in Fromm's Escape from Freedom, although its presence is felt in all his writing. Automaton conformity describes the process of social manipulation that results in the person's striving to be exactly the same as he or she imagines the majority to be. When we succumb to such conformity, we become "cogs in the bureaucratic machine, with our thoughts, feelings, and tastes manipulated by the government industry and the mass communications that they control." 59 The flight into automaton conformity was one of the two possible responses Fromm identified to the fear of freedom (the other being to seek refuge in submission to fascist and totalitarian regimes). ${ }^{60}$

58 Cf. Ira Shor, When Students Have Power: Negotiating Authority in a Critical Pedagogy (Chicago: University of Chicago Press, 1996). Shor relates a story of one class in which he tried to fully share with his students control of the curriculum and of the classroom. After twenty years of practicing critical teaching, he unexpectedly found himself faced with a student uprising that threatened the very possibility of learning. He then works to weave together student voices and thick descriptions of classroom experience with pedagogical theory to illuminate the power relations that must be negotiated so that true learning may take place.

${ }^{59}$ Fromm, To Have or to Be? 12.

${ }^{60}$ Fromm also expresses the two as historical escape routes: conforming to majorities (the "democratic" way out) and conforming to the will of autocratic leaders (the fascist way out). By a specifiable mechanism, these escapes degrade the individual, making him a compulsive, conforming automaton, destroying his freedom and the integrity of his individual self, while at the same time insidiously inducing him to conceive of himself as free and subject only to himself. But, Fromm argues, the discomforts and diseases of individuation-the price which has had to 


\section{AGAINST ALIENATION}

Of these two avenues, it is automaton conformity that is the most subtle and intriguing and ultimately the most alienating. The individual attempts to escape the burden of freedom "by transforming himself into a small cog in the machine, well fed, and well clothed . . . yet not a free man but an automaton."61 The subtlety of automaton conformity is that the pressure to conform is applied internally, not externally, an example of disciplinary power in action. People want to conform to a much higher degree than they are forced to conform, at least in the Western democracies. The authority one is submitting to by conforming is anonymous: the authority of imagined common sense, public opinion, and conventional wisdom. Fromm sounded a distinctively Foucauldian note in his observation that in anonymous authority both command and commander have become invisible, obscured by social habit and political ideology. Information about the correct ways to think and act is inscribed in the cultural DNA.

Following Sigmund Freud, Fromm posited that it is not only individuals who can be sick (neurotic, schizoid or in a false consciousness), but the whole society can be pathogenic. He calls this collective sickness the pathology of normalcy. He attacks the then prevailing conception of mental health, which saw socialization or a patient's restoration to citizenship as the defining characteristics of mental health. This definition of mental health was originally put forward in the interwar years by Adolf Meyer, one of the founding fathers of American psychiatry who saw mental disorder not as a disease but as a functional deficit that he interpreted in terms of maladaptation, or maladjustment. A person who suffers from a mental disorder is a social failure, and the main task of physicians is to help patients adapt to their environment. Fromm turned this conformist conception of mental health on its head by asserting that it is the society that should be adjusted to the true needs of its citizens and that so-called normalcy is in fact a symptom of social pathology. ${ }^{62}$ He claimed that people who cannot stand the humdrum boredom of normal life may develop neurotic symptoms in order to make their lives more meaningful. Indeed, a main characteristic of normalcy is boredom, which Fromm regarded as one of the greatest tortures. ${ }^{63}$ Since conformity to social demands can sometimes lead to mental illness, it is necessary to restructure the society so that it no longer produces mental disturbances that go by the name of normalcy. From the standpoint of normative humanism we must arrive at a

be paid for the liberation of new productive forces-need not lead to new submissions. The study of society need not continue to be a branch of pathology. Man's alternative to the false, unhealthy escapes from freedom is to conform to Fromm's norm, to unite himself with the world in the spontaneity of love and productive work, to realize a spontaneous relationship which connects the individual with the world without eliminating his individuality, to join the world in love and work, in the genuine expression of his emotional, sensuous, and intellectual capacities. Escape from Freedom, 23.

${ }^{61}$ Ibid., xii.

${ }^{62}$ Fromm, The Sane Society, 72, 193.

${ }^{63}$ Erich Fromm, "Medicine and the Ethical Problem of Modern Man," in The Dogma of Christ and Other Essays on Religion, Psychology and Culture (New York: Holt, Rinehart, and Winston, 1963), 169-190. 
different concept of mental health; the very person who is considered healthy in the categories of an alienated world, from the humanistic standpoint appears as the sickest one-although not in terms of individual sickness, but of the socially patterned defect.

Fromm's description of automaton conformity also echoes Gramsci's writing on hegemony. The power of anonymous authority comes from its allpervasive, yet invisible, nature. Like fish unaware of the water in which they live, citizens swim unsuspectingly in the ocean of anonymous authority. We are surrounded by an "atmosphere of subtle suggestion which actually pervades our whole social life. . . one never suspects that there is any order which one is expected to follow." ${ }^{64}$ Under the enveloping influence of anonymous authority, the individual ceases to be himself; he adopts entirely the kind of personality offered to him by cultural patterns and he becomes exactly as all others are and as they expect him to be. Any anxiety people might feel about this kind of existence concerns whether or not they are sufficiently assiduous in pursuing and realizing the pattern of conformity. The automaton conformist's credo can be summarized thus: "I must conform, not be different, not stick out; I must be ready and willing to change according to the changes in the pattern; I must not ask whether I am right or wrong, but whether I am adjusted, whether I am not "peculiar," not different." 65

Automaton conformity has crucial consequences, according to Fromm. Although freedom of thought, speech, and action are cornerstones of American ideology, he believed automaton conformity had worked to erase these elements from the culture. In his view, original decision is a comparatively rare phenomenon in a society which supposedly makes individual decision the cornerstone of its existence. We venerate the ideal of a society full of staunchly rugged individuals defending the right to think, say, and do whatever they wish, but the reality is that we have become automatons who live under the illusion of being self-willing individuals; everybody and everything has become instrumentalized.

This decline in originality of thought and decision inevitably worked to kill critical thinking. As we strive to conform to anonymous authority, and as we feel increasingly powerless in the face of the massive structures (corporations, political parties, labor unions) and forces (advertising, political propaganda) confronting us, we lose the capacity to think critically. In Fromm's view, these methods of dulling the capacity for critical thinking are more dangerous to our democracy than many of the open attacks against it. We are unable to see the big picture, to realize that we are part of a system that operates deliberately to diminish our agency and suppress our ability to ask critical questions. It was clear to him that a most effective way of paralyzing the ability to think critically is the destruction of any kind of structuralized picture of the world, that is, a worldview that sees everything in their positive, unalienated interconnections and productive synthesis, or in other words, a

\footnotetext{
${ }^{64}$ Fromm, Escape from Freedom, 190.

${ }^{65}$ Fromm, The Art of Loving, 153.
} 


\section{AGAINST ALIENATION}

worldview in which theory and practice, vita contemplativa and vita activa, would function in unison. Life becomes seen as composed of many little pieces, each separate from the other and lacking any sense as a whole. Facts lose the specific quality which they can have only as parts of a structuralized whole and retain merely an abstract, quantitative meaning. This destructuralization phenomenon is most poignantly felt in some of educational methods used today which in effect further discourage original thinking and spontaneity. One is the overemphasis on knowledge of facts. The pathetic superstition prevails that by knowing more and more facts one arrives at knowledge of reality; thus hundreds of scattered and unrelated facts are dumped into the heads of students, and as a consequence, their time and energy are taken up by learning more and more facts to the extent that there is little left for thinking.

\section{Teaching a Structuralized Worldview}

In advocating the teaching of a structuralized worldview, Fromm offers us a clear purpose for education, one that fits firmly within the tradition of helping young people learn democracy. A structuralized view of the world requires a familiarity with history, political economy, and sociology. He argued that the development of such a view was really only possible with adequately prepared learners. In his way of thinking, people not only had a greater interest in developing such a perspective, but they also possessed the intellectual capability to do this in a way that was not possible for them in their formative years. An interpretation of Fromm's call to develop a structuralized picture of the world is something that Fromm's contemporary, Charles Wright Mills, attempted to provide. Like Fromm, Mills had written a popular text on Marxism, and like him he had thought deeply about the social purpose of education. In Mass Society and Liberal Education, Mills anticipated Fromm's argument in The Sociological Imagination that a structuralized view of the world emerges when people learn "to turn personal troubles and concerns into social issues and rationally open problems." " If people start to see situations in their

${ }^{66}$ Charles Wright Mills, The Sociological Imagination (New York: Oxford University Press, 1959), 12. Mills coined the term sociological imagination to describe the process of linking individual experience with social institutions and one's place in history. By this perspective, people in poverty might link their personal circumstances to the social forces relevant to their present condition. He argued that nowadays men often feel that their private lives are a series of traps. He maintained that people are trapped because their visions and their powers are limited to the close-up scenes of job, family and neighborhood, and are not able to fully understand the greater sociological patterns related to their private troubles. Underlying this feeling of being trapped are the seemingly uncontrollable and continuous changes to society. He mentions unemployment, war, marriage and life in the city as examples where tension between private trouble and public issues becomes apparent. He offers a solution to this feeling of being trapped. He argues that because neither the life of an individual nor the history of a society can be understood without understanding both, we need to develop a way of understanding the interaction between the individual lives and society. This understanding is what Mills calls sociological imagination: the quality of mind which allows one to grasp history and biography and the relations between the two within society. Mills believed, however, that ordinary people do not possess the quality of mind essential to grasp the interplay of man and society, of 
private lives as concrete manifestations of broader social and political contradictions, they will see that changing their individual lives is impossible without political action. Hence, "to the extent that the adult college is effective, it is going to be political; its students are going to try to influence decisions of power." ${ }^{\circ 7}$

Fromm and Mills both emphasized the necessity of peoples' understanding how the particular circumstances of their lives were produced by the intersection of political decisions, social and economic trends, and the workings of capital. Divorce, unemployment, unhappiness, and isolation must be interpreted not as the capricious workings of a cruel fate but as the result of decisions made by the (often secret) few in positions of enormous power. Factories close and jobs are lost not because the economy somehow catches a cold; these things happen because companies relocate to other states or countries where non-unionized labor is cheap and plentiful, or because governing boards decide to merge with other boards, or because by "downsizing" or "rightsizing," a company's stockholder dividends are likely to be higher. Even the most private and traumatic tearings in the fabric of personal relationships, such as divorce, should be understood as social and political phenomena. The restlessness and unfulfilled desires that lay behind a divorce were manifestations of the receptive orientation that predisposed people to want more and more with no prospect of more than temporary satisfaction - the eternally expectant ones forever doomed to be the eternally disappointed ones, as Fromm put it. Alternatively, divorce, unhappiness, and isolation were the result of people's need to leave their home communities in search of work that would provide them with the financial means to satisfy their appetite for the commodities they felt were necessary to create the good life.

A structuralized view of the world moved people away from magical consciousness (in Freire's terms) to an awareness of how ideology, culture, and economics intersected to shape individual lives. Possessing such an awareness was the necessary precursor to deciding that alienating social arrangements could be reshaped by individual and collective will. Helping people develop a structuralized view of the world was one way education could lay the foundations for social action. Without this view, there was little chance that people could recognize, let alone oppose, the consensus of stupidity that would most likely ensure environmental self-destruction. The task of education was to break the chains of illusion that bound people to an individualized view of life and to develop in them the capacity for reason: "the capacity to recognize the unreality of most of the ideas that man holds, and to penetrate to the reality veiled by the layers and layers of deception and ideologies."

biography and history, of self and world. See also Charles Wright Mills, Mass Society and Liberal Education (Chicago: Center for the Study of Liberal Education for Adults, 1954); and Charles Wright Mills, The Marxists (New York: Dell, 1962).

${ }^{67}$ Mills, The Sociological Imagination, 16.

${ }^{68}$ Fromm, Beyond the Chains of Illusion, 179. 


\section{AGAINST ALIENATION}

\section{Learning as Democratic Participation}

If human activity is paralyzed in the capitalist system, then the goal of socialism must be to restore full humanity by restoring activity in all spheres of life. Politically this means the creation of a participatory democracy that would liberate people from the commodified, "having" mode of existence. Fromm proposed a network of face-to-face groups that would coalesce into town meeting-sized assemblies of not more than 500 people. This network of assemblies would constitute a Lower House to monitor and advise the elected legislature on a day-to-day basis.

Within these groups, people were enjoined to behave in ways appropriate to participatory democracy. In outlining these ways, Fromm focused quite concretely on the conditions and dispositions for dialogic learning. In participatory learning groups, members are disposed to help others learn because they regard their peers' learning as crucial to their own individual development. They strive to understand what others are saying and to help the other to clarify his thought rather than to force him to defend formulations about which he may have his own doubts. People in these groups are in a "being" mode of learning and strive for the loss of ego that the best teachers also strive for: "They respond spontaneously and productively; they forget about themselves, about the knowledge, the positions they have. Their egos do not stand in their own way . . . they carefully respond to the other person and that person's ideas. They give birth to new ideas because they are not holding on to anything."

Fromm can therefore be seen as reprising some sentiments regarding the nature and function of discussion groups in a democratic society and then adding a more psychological sheen by focusing on the loss of ego. To a social psychologist such as Fromm, diminishing egocentrism and opposing capitalist commodification are two sides of the same coin. When learners in discussion groups are disposed to help others learn they also help the other to transcend his or her egocentricity. In furthering the loss of ego, the conversation ceases to be an exchange of commodities (information, knowledge, status) and becomes a dialogue in which it does not matter anymore who is right. As conversation as combative posturing recedes, so "the duelists begin to dance together. . . with joy.",70

To Fromm, the knowledge that one's decision has an effect is crucial to the functioning of participatory democracy and the missing element in many superficially democratic formats. What is true for democratic experiments in the wider society is just as true for the classroom. A basic indication that a degree of democracy is in place is that the opinions people express have some impact on the situation in which they find themselves. This does not mean that the will of the majority must, by definition, prevail. Indeed, the minority's perspective may be the more valid one (as would be the case in an insistence

\footnotetext{
${ }^{69}$ Fromm, To Have or to Be?, 42

${ }^{70}$ Ibid.
} 


\section{R. PANGILINAN}

that dominant ideology obfuscates the extent of repressive power). But where hard-fought decisions emerge from true dialogue, the originators of those decisions need to know that they will have some effect. Otherwise, why bother?

Fromm believed that opposing people's uncritical adherence to dominant ideology required an educator to stick to one's convictions even though they are unpopular. To do what was right, one had to call forth "the courage to judge certain values as of ultimate concern —and to take the jump and stake everything on these values." ${ }^{, 71}$ In staking everything on helping people overcome the alienation inherent in capitalist society, Fromm's work reaches out to us from across the millennial divide.

The Graduate School, University of Santo Tomas, Philippines

\section{References}

Adorno, Theodor, The Culture Industry: Selected Essays on Mass Culture, ed. by J.M. Bernstein (London: Routledge, 1991).

Coute, David, The Illusion: An Essay on Politics, Theatre and the Novel (London: Deutsch, 1971).

Dant, Tim, Critical Social Theory: Culture, Society, and Critique (London: Sage, 2003).

Freire, Paulo, Pedagogy of the Oppressed, trans. by Myra Bergman Ramos, 30

(New York: Continnum, 2000).

Fromm, Erich, The Art of Being (New York: Continuum, 1992). , The Art of Loving: An Enquiry into the Nature of Love (New York: Harper \& Row, 1956). Beyond the Chains of Illusion: My Encounter with Freud and Marx

(New York: Continuum, 2003).

, The Dogma of Christ and Other Essays on Religion, Psychology and

Culture (New York: Holt, Rinehart, and Winston, 1963). , Escape from Freedom, $4^{\text {th }}$ ed. (New York: Avon Books, 1966). The Heart of Man: Its Genius for Good and Evil (New York: Harper \& Row, 1964). Man for Himself: An Inquiry into the Psychology of Ethics (London: Routledge, 2003). , May Man Prevail? An Inquiry into the Facts and Fictions of Foreign Policy (New York: Doubleday, 1961).

, Marx's Concept of Man. With a translation of Marx's Economic and Philosophic Manuscripts by T.B. Bottomore (London: Continuum, 2004). 1994).

On Being Human, ed. by Rainer Funk (New York: Continuum, The Revolution of Hope: Toward a Humanized Technology (New York: Harper \& Row, 1974).

${ }^{71}$ Fromm, The Art of Loving, 126. 
, The Sane Society (New York: Holt, Rinehart and Winston, 1955). , ed., Socialist Humanism: An International Symposium (New York: Allen Lane the Penguin Press, 1965). To Have or to Be? (New York: Harper \& Row, 1976).

Fromm, Erich, Daisetz Teitaro Suzuki and Richard De Martino, Zen Buddhism and Psychoanalysis (New York: HarperCollins, 1970).

Fromm, Erich and Mary Josephine, eds., Man Alone: Alienation in Modern Society (New York: Dell, 1962).

Horton, Myles, The Long Haul: An Autobiography (New York: Doubleday, 1990).

Lindeman, Eduard, The Meaning of Adult Education (Buffalo: Harvest House, 1961).

Marcuse, Herbert, "Repressive Tolerance," in A Critique of Pure Tolerance, ed. by Robert Paul Wolff, Barrington Moore and Herbert Marcuse (Boston: Beacon, 1965), 81-119.

Marx, Karl, Capital: A Critique of Political Economy, trans. by Ben Fowkes (London: Penguin, 1976). , Early Writings, trans. by Rodney Livingstone and Gregor Benton (New York: Vintage Books, 1975). , Grundrisse: Foundations of the Critique of Political Economy, trans. by Martin Nicolaus (New York: Penguin, 1973).

Mills, Charles Wright, The Marxists (New York: Dell, 1962). , Mass Society and Liberal Education (Chicago: Center for the Study of Liberal Education for Adults, 1954). 1959). The Sociological Imagination (New York: Oxford University Press,

Newman, Michael, Defining the Enemy: Social Action in Adult Education (Sydney: Stewart Victor, 1994) < http://www.michaelnewman.info/docs/ defining the enemy.pdf $>, 16$ March 2009).

, Maeler's Regard: Images of Adult Learning (Sydney: Stewart Victor, $1999)<$ http://www.michaelnewman.info/docs/maelers regard.pdf $>$, 16 March 2009.

Olaniyan, D.A. and T. Okemakinde, "Human Capital Theory: Implications for Educational Development," in European Journal of Scientific Research, $24: 2$ (December 2008) < http://www.eurojournals.com/ejsr 24_2 01.pdf>, 6 February 2010.

Ollman, Bertell, Marx's Conception of Man in Capitalist Society, $2^{\text {nd }}$ ed. (Cambridge: Cambridge University Press, 1976).

Orwell, George, "Politics and the English Language," in A Collection of Essays (New York: Doubleday, 1999) < http://orwell.ru/library/essays/ politics/english/e polit>, 20 March 2009.

Pangilinan, Rafael D., "Fromm's Search for a Humanistic Alternative," in $A d$ Veritatem, 8:2 (March 2009).

Postone, Moishe, Time, Labor, and Social Domination: A Reinterpretation of Marx's Critical Theory (Cambridge: Cambridge University Press, 1993).

Schaar, John, Escape from Authority: The Perspectives of Erich Fromm (New York: Basic Books, 1961). 


\section{R. PANGILINAN 29}

Shor, Ira, Empowering Education: Critical Teaching for Social Change (Chicago: Chicago University Press, 1992).

When Students Have Power: Negotiating Authority in a Critical Pedagogy (Chicago: University of Chicago Press, 1996).

Timbreza, Florentino T., Alternative to a Dead God (Manila: DLSU Press, 2001).

Welton, Michael Robert R., ed., In Defense of the Lifeworld: Critical Perspectives on Adult Learning (Albany: State University of New York Press, 1995).

Wiggerhaus, Rolf, The Frankfurt School: Its History, Theories, and Political Significance (Cambridge: MIT Press, 2003). 